\title{
Mexicana rubra sp. nov. and Encotyllabe cf. spari Yamaguti, 1934 (Monogenea) of Orthopristis ruber (Cuvier, 1830) from the Brazilian Coast off Rio de Janeiro
}

\author{
A. C. A. CAMARGO 1 , J. L. LUQUE², C. P. SANTOS ${ }^{1 *}$
}

${ }^{1}$ Laboratório de Avaliação e Promoção da Saúde Ambiental, Instituto Oswaldo Cruz, Fiocruz, Rio de Janeiro, RJ, Brazil, *E-mail: cpsantos@ioc.fiocruz.br, ${ }^{2}$ Departamento de Parasitologia Animal, Universidade Federal Rural do Rio de Janeiro, BR 465, Km 7, CEP 23890-000, Seropédica, Brasil

\section{Article info}

Received March 14, 2017 Accepted August 17, 2017

\begin{abstract}
Summary
Mexicana rubra sp. nov. and Encotyllabe cf. spari are described from the gills of the marine fish Orthopristis ruber (Haemulidae) caught off Rio de Janeiro, Brazil. Morphological, ultrastructural and genetic data are provided. The main diagnostic features of this new species of ectoparasite are a posteriorly bipartite testis, a ventral bar with three deep bowed projections and a dorsal bar with two deep, conspicuous, antero-lateral indentations. Genetic data on Mexicana rubra sp. nov. are based on the ITS1, 5.8S and partial 18S and 28S rDNA. This is the sixth known species of Mexicana Caballero \& Bravo-Hollis, 1959, a key to which is also presented. Encotyllabe cf. spari Yamaguti, 1934 is described from the same host, with new ultrastructural data and new partial 18S and 28S rDNA sequences. A phylogenetic analysis based on partial $18 \mathrm{~S}$ and $28 \mathrm{~S}$ sequences is undertaken for both species.

Keywords: Monogenea; Dactylogyridae; Capsalidae; Genetic data
\end{abstract}

\section{Introduction}

The Haemulidae (Osteichthyes) are marine fish species distributed in the Atlantic, Indian and Pacific Oceans, but may also occur in estuaries (Palazón-Fernández, 2007). In the Atlantic, species of Orthopristis Girard, 1858, so-called "grunts" due to their ability to produce sounds when in danger, are found in areas with a stony bottom, sandy beaches, bays and estuarine areas, and are distributed between the Caribbean off Honduras to the coast of southern Brazil (Burkenroad, 1930; Tavolga \& Wodinsky, 1965; Menezes \& Figueiredo, 1980).

The parasites of Orthopristis ruber (Cuvier, 1830) have been studied by Amato (1982 a, b, c; 1983 a, b), Bashirullah et al. (1987), Luque et al. (1992; 1993a, b; 1996a) and Paschoal et al. (2014), in addition to their citation in the checklists of Paschoal et al. (2015). During a survey of the monogeneans of $O$. ruber off Rio de Janeiro, Brazil, a new species of Mexicana Caballero \& Bravo-Hollis,
1959 parasitizing the gills was found, the morphology and genetic profiles of which are described herein. In addition, specimens identified as Encotylabe cf. spari Yamaguti, 1934, also from the gills, are described along with new ultrastructural details and genetic data based on the partial 18S and 28S rDNA genes. The phylogenetic position of both species is discussed.

\section{Material and Methods}

Specimens of Orthopristis ruber were collected off Urca on the Brazilian coast of Rio de Janeiro (22 $\left.56^{\prime} 49^{\prime \prime} \mathrm{N}, 43^{\circ} 9^{\prime} 50^{\prime \prime} \mathrm{W}\right)$ during 2015 and transferred fresh to the laboratory. The gills were removed and examined in a saline medium under a stereomicroscope. Any parasites recovered were fixed in $70 \%$ or $100 \%$ ethanol. Some specimens were mounted in Berlese medium to improve the visibility of the sclerotised structures. Alternatively, some specimens were stained in Mayer's paracarmine or Gomori's trichrome

\footnotetext{
$\bar{*}$ - corresponding author
} 
and mounted in Canada balsam. Measurements are presented in micrometers, with the mean followed by the range in parentheses, unless otherwise stated. The measurements of the anchors were based on Vignon and Sasal (2010). Drawings were made with the aid of a drawing tube attached to the Olympus CX31 microscope. Prevalence and intensity data follows Bush et al. (1997). Representative specimens were deposited at the Helminthological Collection of the Instituto Oswaldo Cruz (CHIOC), Rio de Janeiro, Brazil. For comparative purposes, paratypes (CHIOC 33.109 and 33.110) of Mexicana atlantica Luque, Amato \& Takemoto, 1992 and micrographs of Mexicana bychowskyi Caballero \& Bravo-Hollis, 1959 (holotype and paratypes 216-24) and Mexicana littoralis Caballero \& Bravo-Hollis, 1961 (holotype 218-3) from Colección Nacional de Helmintos (CNHE), Instituto de Biología, Universidad Nacional Autónoma de México (UNAM), Mexico were studied.

For scanning electron microscopy (SEM), specimens were postfixed for $24 \mathrm{~h}$ at room temperature in a solution of $1 \%$ osmium tetroxide and $0.8 \%$ potassium ferrocyanide, dehydrated through a graded alcohol series, critical-point dried and sputter coated with gold. The samples were examined using a JEOL JSM-6390 LV SEM, from the Plataforma de Microscopia Eletrônica do Instituto Oswaldo Cruz, at an accelerating voltage of $15 \mathrm{kV}$.

\section{Genetic analysis}

The DNA extraction was performed using the phenol-chloroform method as described by Billings et al. (1998) and a set of primers were used to amplify different regions of the DNA. The rDNA region 28S was amplified by PCR using the primers $C 1$ (5' - ACCCGCTGAATTTAAGCAT - 3') and D2 (5' -TGGTC CGTGT TTCAA GAC - 3') (after Chisholm et al., 2001). The partial 18S, ITS1 and 5.8S were amplified using the primers S1 (5'-TTCCG ATAAC GAACG AGACT -3') and H7 (5'- GCTGC GTTC TTCAT CGATA CTCG -3') (Sinnappah et al., 2001). PCRs were carried out using cycling parameters as previously described by these authors. The PCR products were analysed by electrophoresis in $1.5 \%$ agarose in Tris-borate EDTA gels, stained with SyberGreen (Invitrogen, Eugene, Oregon, USA) and photographed under UV transillumination. Amplified PCR products were purified with Ex-

Table 1. List of the species of Monogenea and outgroups used in the phylogenetic analyses of Mexicana rubra sp. nov. and Encotyllabe cf. spari using sequences of the partial $18 \mathrm{~S}$ and partial 28S rDNA genes.

\begin{tabular}{|c|c|c|c|}
\hline Species & Family & $18 S$ rDNA & $28 \mathrm{~S}$ rDNA \\
\hline Benedenia epinepheli (Yamaguti,1937) & Capsalidae & EU707802 & EU707803 \\
\hline Benedenia sp. & Capsalidae & AJ228774 & \\
\hline Benedenia lutjani (Whittington \& Kearn, 1993) & Capsalidae & & AY033939 \\
\hline Capsala martinieri (Bosc, 1811) & Capsalidae & AJ276423 & AF382053 \\
\hline Capsala laevis (Verrill, 1875) & Capsalidae & & JN980396 \\
\hline Encotyllabe chironemi (Robinson, 1961) & Capsalidae & AJ228780 & AF382054 \\
\hline Encotyllabe cf. spari (Yamaguti, 1934) & Capsalidae & KY553150 & KY553149 \\
\hline Encotyllabe caballeroi (Velasquez, 1977) & Capsalidae & & AF026112 \\
\hline Encotyllabe caranxi (Lebedev, 1967) & Capsalidae & & FJ971990 \\
\hline Bravohollisia rosetta (Lim, 1995) & Dactylogyridae & EF152322 & DQ537364 \\
\hline Bravohollisia tecta (Bychowsky \& Nagibina, 1970) & Dactylogyridae & KJ571020 & KJ571012 \\
\hline $\begin{array}{l}\text { Euryhaliotrematoides pirulum (Plaisance \& } \\
\text { Kritsky, 2004) (=Euryhaliotrema pirulum) }\end{array}$ & Dactylogyridae & AY820607 & \\
\hline $\begin{array}{l}\text { Euryhalitrematoides triangulovagina (Yamaguti, } \\
\text { 1968) (=Euryhaliotrema triangulovagina) }\end{array}$ & Dactylogyridae & AY820608 & \\
\hline $\begin{array}{l}\text { Euryhaliotrematoides microphallus (Yamaguti, } \\
\text { 1968) (=Euryhaliotrema microphallus) }\end{array}$ & Dactylogyridae & AY820606 & \\
\hline $\begin{array}{l}\text { Haliotrematoides spinatus (Kritsky \& Mendoza- } \\
\text { Franco in Kritsky, Yang \& Sun, 2009) }\end{array}$ & Dactylogyridae & & KC663678 \\
\hline $\begin{array}{l}\text { Haliotrematoides guttati (Garcia-Vargas, Fajer- } \\
\text { Ávila \& Lamothe-Argumedo, 2008) }\end{array}$ & Dactylogyridae & JN054406 & KC663673 \\
\hline $\begin{array}{l}\text { Ligophorus uruguayensis (Failla Siquer \& } \\
\text { Ostrowski de Núñez, 2009) }\end{array}$ & Dactylogyridae & & KF442630 \\
\hline Ligophorus funnelus (Soo \& Lim, 2012) & Dactylogyridae & & KM221914 \\
\hline Mexicana rubra sp. nov. & Dactylogyridae & KY553146 & KY553148 \\
\hline Microcotyle sebastis (Goto, 1894) & Microcotylidae & AJ287540 & AF382051 \\
\hline
\end{tabular}


oSap-IT (USB® Products Affymetrix Inc., Cleveland, Ohio, USA). DNA cycle sequencing reactions were performed using BigDye Terminator v.3.1 (Applied Biosystems, Foster City, CA, USA) and automated sequencing was done using the Sequencing Platform at the Fundacão Oswaldo Cruz-PDTIS/FIOCRUZ in Brazil. Sequences of both strands were generated, edited and aligned by using the MEGA version 7.0 software (Kumar et al., 2015). Sequences were compared to others available in the GenBank database using the BLASTN program from the National Center for Biotechnology Information (NCBI) server (http://www.ncbi. nlm. nih.gov/BLAST) (Altschul et al., 1990). Taxa, for which sequences from GenBank were used for the phylogenetic analysis, are listed in Table 1. To examine the phylogenetic relationships, the nucleotide sequences were analysed using the CLUSTAL W algorithm of the MEGA 7.0 package (Thompson et al., 1994). Maximum likelihood (ML) phylogenetic trees (Felsenstein, 1981) were inferred using the MEGA 7.0 using the generalised time-reversible (GTR) and gamma distribution with invariant sites $(G+I)$ for the analysis of 18S rDNA and Kimura2 (K2) with invariant site (I) for partial $28 \mathrm{~S}$ rDNA. The tree was resampled by 5,000 bootstrap replicates to evaluate the reliability of the groups.
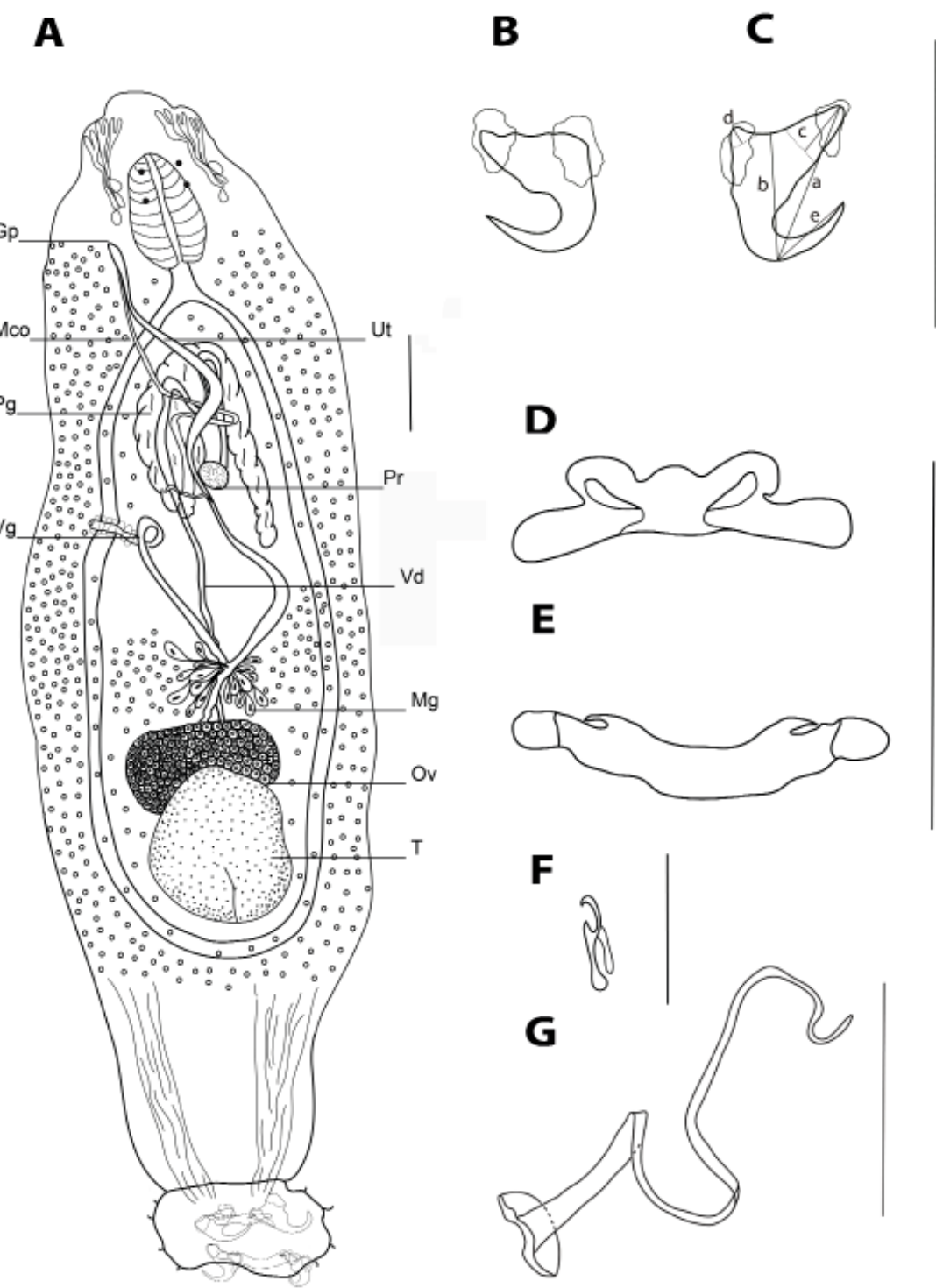

$\mathbf{E}$
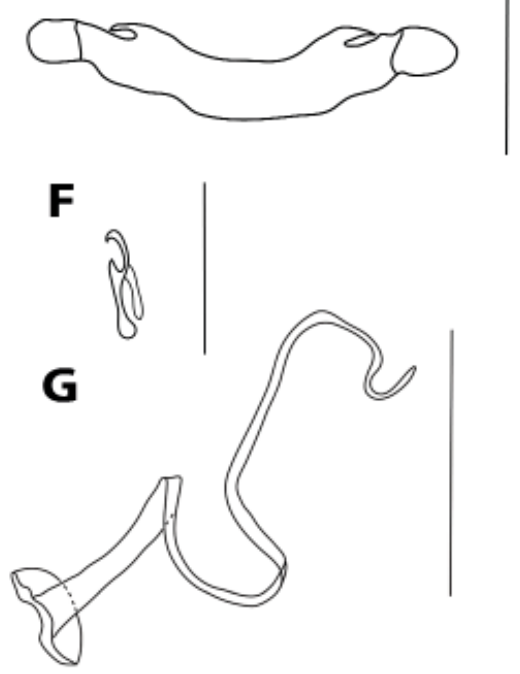

Fig. 1. Mexicana rubra sp. nov. (A) Holotype, ventral view; (B) Ventral anchor; (C) Dorsal anchor; (D) Ventral bar; (E) Dorsal bar; (F) Hook; (G) Copulatory organ. $a=$ length of base; $b=$ length of inner root; $c=$ length of outer root; $d=$ length of point; $e=$ total length of marginal hook.

The reproductive organ components are abbreviated as follows: $\mathrm{T}=$ testis; $\mathrm{Ov}=$ ovary; $\mathrm{Mg}=$ Mehlis' gland; $\mathrm{Vg}=$ vagina; $\mathrm{Pr}=$ prostatic reservoir; $\mathrm{Pg}=$ prostatic glands; $\mathrm{Vd}=$ vas deferens; $\mathrm{Mco}=$ male copulatory organ; $\mathrm{Ut}=$ uterus; $\mathrm{Gp}=$ genital pore. Scale-bars: Figure $\mathrm{A}=100 \mathrm{~mm} ; \mathrm{B}, \mathrm{C}, \mathrm{D}$ and $\mathrm{E}=50 \mathrm{~mm} ; \mathrm{F}=20 \mathrm{~mm} ; \mathrm{G}=100 \mathrm{~mm}$. 


\section{Results}

A total of 101 Orthopristis ruber measuring $13.61(7-25) \mathrm{cm}$ long were examined. The monogeneans Mexicana rubra sp. nov. and Encotyllabe cf. spari Yamaguti, 1934 found on the gills are described below.

Dactylogyridae Bychowsky, 1933

Mexicana Caballero \& Bravo-Hollis, 1959

Mexicana rubra sp. nov. (Fig. 1A-G, Table 2)

Type host: Orthopristis ruber (Cuvier 1830).

Site of infection: Gills.

Type locality: Coast of Rio de Janeiro, off Urca, Brazil.

Specimens deposited: CHIOC numbers 38466 (Holotype), 38467a-c and 38468 (4 paratypes).

Prevalence and intensity: $2.97 \%$ (3 fish infected/ 101 examined); 1 - 7 parasites per fish.

Etymology: The new species is treated as an adjective and refers to the specific name of the host.

Description: (measurements based on 7 adult specimens): Body elongate, with poorly differentiated haptor. Total length 843 (700 950) long and $232(180-360)$ width at the level of ovary (Fig.1A). Cephalic region with three lobes pairs and four eyes similar in size. Pharynx ovoid is $74(62-90)$ long $\times 56.4(47-70)$ wide. Haptor $83(70-95)$ long $\times 122(80-155)$ wide; two pairs of dissimilar anchors and 14 marginal hooks. Ventral anchors: $a=27(26-28)$, $b=16(16-17), c=5(3-7.5), d=5(4-6)$ and $e=25(25-25)$ (Fig. 1B). Dorsal anchors: $a=27(23-30), b=22.5(23-23), c=9$ $(8-10), d=6(5-8)$ and $e=21(15-25)$ (Fig. 1C). Single pair of plates present on either side of anchors. Bars different in size and shape, both with lateral extensions articulated to anchors. Ventral bar is $7-10$ long $\times 35(-)$ wide, with three deep bowed projections; dorsal bar elongate, $5-8$ long $\times 37-40$ wide (39.54), with two conspicuousl antero-lateral indentations (Fig. 2D - E, Table 2). Hooks 14, similar in size and shape, 12 (11 - 13) long, short shank, erect thumb, curved shaft, delicate point, filament $(\mathrm{FH})$ loop almost same length as hook shank (Fig. 1F). Intestinal ceca is confluent forming posteriorly cyclocoel. Testis postovarian is 120 $(100-145) \times 90(75-195)$, bipartite posteriorly. Vas deferens arises from anterior border of testis, extends and dilates anteriorly to form elongated, inverted U-shaped seminal vesicle in pre-equatorial region. Prostatic reservoir identified at the level of seminal vesicle. Male copulatory organ are sclerotized, tubular, sinuous, 260 (242 - 280) long, with expanded piece at the base, genital pore at the level of pharynx (Fig. 1G). Ovary bilobed 87 (73-100) $\times 50(48-55)$. Mehlis' gland is well developed, with pedunculate cells. Vagina is muscular, tubular; vaginal pore dextro-ventral, pre-equatorial. Vitellarium follicular; follicles scattered throughout trunk (extending from level of pharynx almost to peduncle) except in region of reproductive organs. Median uterus rises from ootype to genital pore; and eggs not observed.

\section{Remarks}

Mexicana rubra sp. nov. is the first species of this genus parasitizing 0 . ruber. Its main diagnostic features are the posteriorly bipartite testis, ventral bar with three deep bowed projections and dorsal bar with a pair of conspicuous, deep, antero-lateral indentations. Congeneric species from the Pacific Ocean, in addition to variation in geographical distribution and host, can be differentiated as follows: in the case of Mexicana iannaconi Chero, Cruces, Sáez and Alvariño, 2014 from Peru, by having a completely bipartite testis and larger dorsal and ventral bars; and, in the cases of M. littoralis and M. bychowskyi from Mexico, although possessing a testis which is bipartite only posteriorly, by having a different size and shape of the bars and anchors. The species occurring in the Atlantic Ocean can be readily differentiated, since Mexicana anisotremum Cezar, Paschoal and Luque, 2012 has an entire testis, and the morphologically most similar species, Mexicana atlantica Luque, Amato and Takemoto, 1992, which has also a posteriorly bipartite testis, differs mainly in its host and the shape and size of the bars and anchors. A comparative analysis of the bars of these species is presented in Table 2.

\section{Genetic Analysis}

New sequences of the partial 18S rDNA (KY553146) (482bp), partial 18S, ITS and 5.8S rDNA (KY553148) (1064bp) and partial $28 \mathrm{~S}$ (KY553148) (775bp) have been deposited in the GenBank. The BLAST results for the partial 18S, ITS1 and 5.8S rDNA sequences of $1064 \mathrm{bp}$ indicated a $94 \%$ identity with a species Euryhaliotrematoides sp. (DQ537344) (=Euryhaliotrema sp.), with a $45 \%$ query cover and maximum score of 732 , followed by a $95 \%$ identity, $41 \%$ query cover and maximum score of 693 , with both Dactylogyrus tuba (KJ605445) and Dactylogyrus carpathicus (EF582618). When the ITS1 was analyzed separately, the BLAST result indicated no significant similarity with sequences deposited in GenBank, and, only in the case of the partial 18S, the BLAST indicated a $92 \%$ identity with Euryhaliotrematoides pirulum (AY820607) and E. triangulovagina, with a $98 \%$ cover and total score 676 and 671, respectively. For the partial 28S rDNA, the BLAST results indicated a $86 \%$ identity, $87 \%$ query cover and a maximum score 699 with Haliotrematoides spinatus (KC663678, HQ615995 and KC663677).

\section{Capsalidae Baird, 1853}

Encotyllabe Diesing, 1850

Encotyllabe cf. spari Yamaguti, 1934 (Fig. 3A-G)

Type host: Orthopristis ruber (Cuvier, 1830).

Site of infection: Gills

Type-locality: Coast of Rio de Janeiro, off Urca, Brazil.

Specimens deposited: CHIOC numbers 38463, 38464a, 38464b and 38465 (vouchers).

Prevalence and intensity: 48.51 \% (49 fish infected/ 101 examined); 1 - 6 parasites per fish. 
Table 2. Comparative drawings of bars from Mexicana species. Scale bars: $20 \mu \mathrm{m}$.

Species
M. iannaconi
odriginal article

M. atlantica

Redrawn from original article
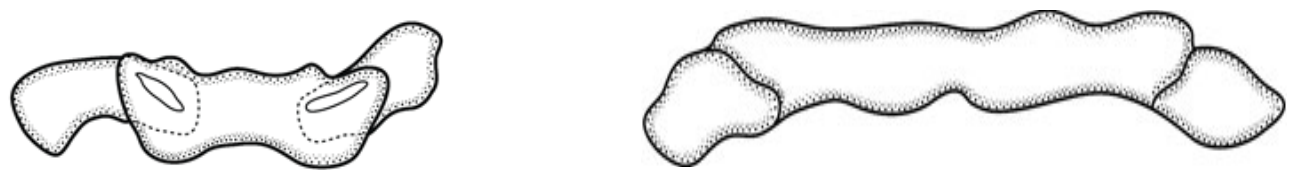

Redrawn

from paratype:

CHIOC 33.109
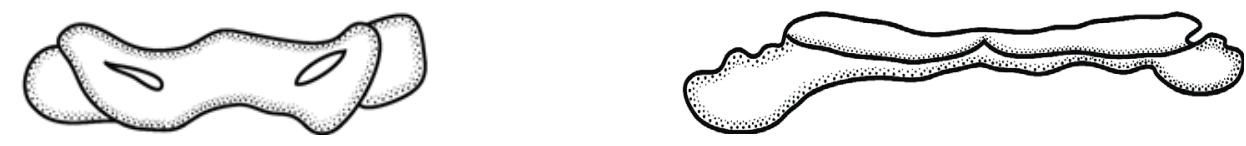

M. bychowsky

Redrawn from

original article
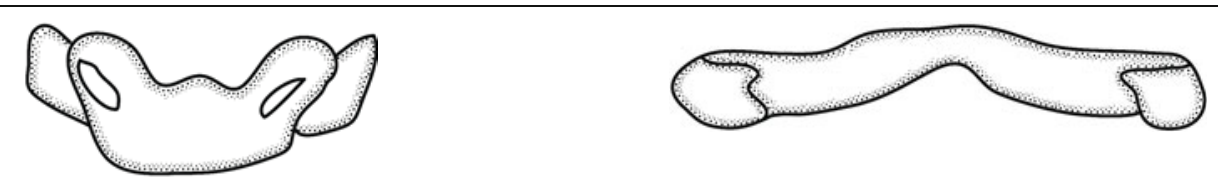

Redrawn from
photograph of
Voucher: CNHE
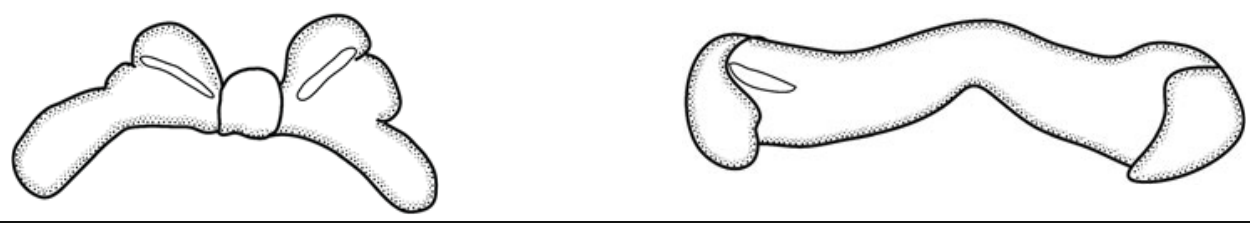

\section{M. littoralis \\ Redrawn from \\ original article}
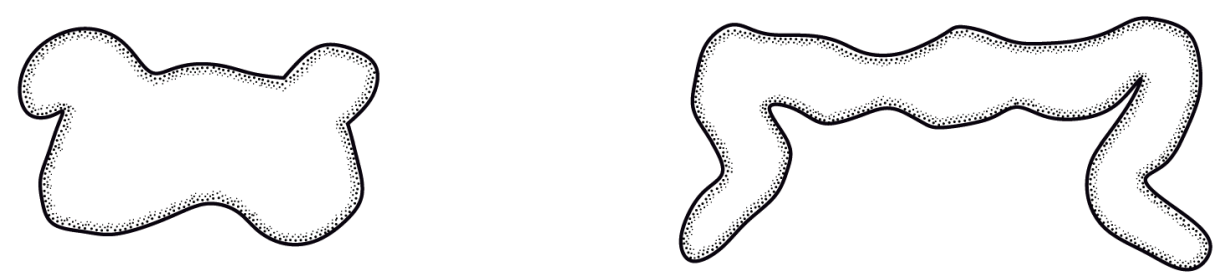

\section{M. anisotremum \\ Redrawn from}

original article
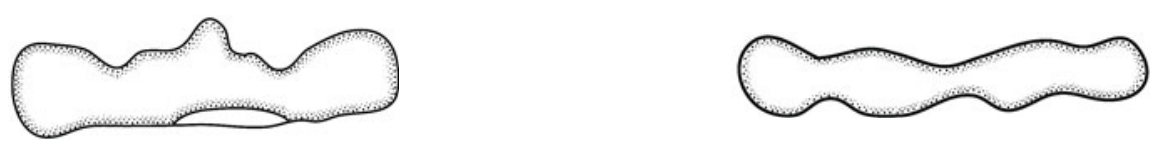

M. rubra sp. nov.
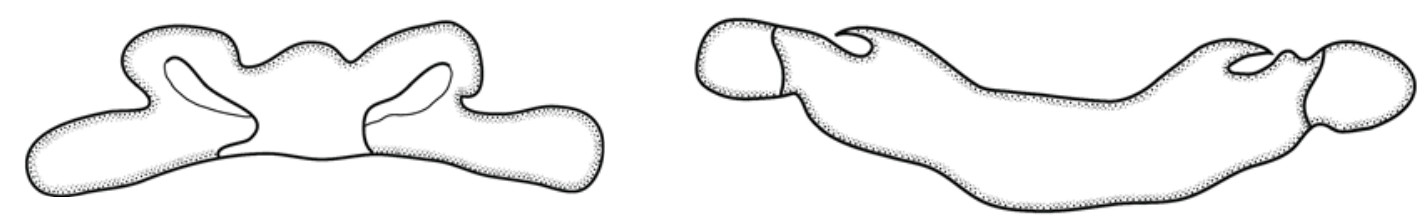
Description: (measurements based on 10 specimens): Body ellipsoidal, 3.02 (2.3 - 4.34) mm long and 1130 (780 -1.650) mm wide; anterior suckers, $196(160-280) \times 206(145-280)$, with projecting crenulate lobes (Fig. 2A). Mouth bordered by digitiform projections on anterior border. Pharynx is muscular, $338(260-460) \times$ $324(290-400)$. Two pairs of eyespots are at level of pharynx. Intestinal ceca branched posteriorly, extending to base of peduncle, not confluent. Peduncle $300-400$ (350). Haptor is bell-shaped $529(470-610) \times 532(375-720)$; marginal membrane $11-13$ (12) wide; one pair of large anchors, one pair of small anchors and 14 marginal hooks. Large anchors $233(200-280) \times 95(80-110)$ (Fig. 2B); small anchors 20 - 25 (Fig. 2C); marginal hooks 10 long (Fig. 2D). Testes two juxtaposed, pre-equatorial, differ in size; left testis $124(100-210) \times 124(105-170)$, right testis $126(100-$ $170) \times 128(100-170)$. Efferent canal emerges from each testis, uniting to form vas deferens which penetrates bulbous cirrus sac to become seminal vesicle and ejaculatory duct; cirrus elongate. Prostatic reservoir is inside cirrus sac (Fig. 2E). Ovary noticed pretesticular, oval, $199(140-250) \times 179(125-250)$. Uterus long, thin, passes cirrus sac and ootype to open via genital pore located close to pharynx. Vitelline follicles are dense, extended from level of pharynx almost to the base of peduncle. Vitelline reservoir is pre-ovarian, $137(80-240) \times 124(80-200)$. Mehlis' gland surrounds ootype. Vagina found ventrally, at the anterior level of ovary. Eggs are triangular, $90 \times 110$; anterior 525 and posterior filament 70 long (Fig. 2F).

\section{Scanning electron microscopy}

Body smooth, folded laterally, with distal peduncle and oval haptor (Fig. 3A). Anterior suckers bordered anteriorly by crenulate lobes (Fig. 3B). Mouth ventrally, between anterior suckers, bearing several digitiform projections (Fig. 3B - C). Haptor bordered by small
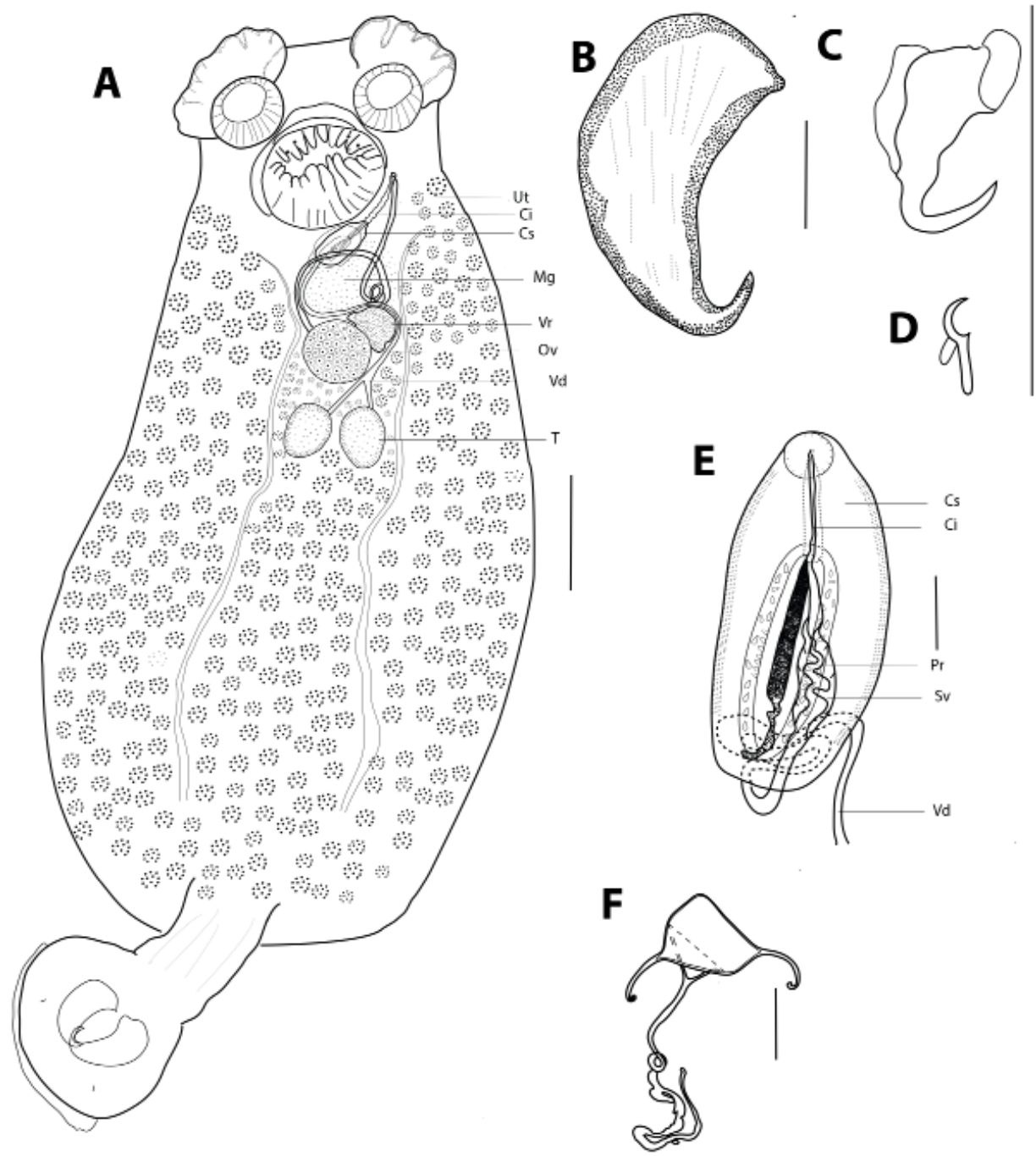

Fig. 2. Encotyllabe cf spari. (A) Body, ventral view; (B) Large anchor; (C) Small anchor; (D) Hook; (E) Copulatory organ, (F) Egg. The reproductive organ components are abbreviated as follows: $\mathrm{T}=$ testis; $\mathrm{Vd}=$ vas deferens; $\mathrm{Vr}=$ vitelline reservoir; $\mathrm{Ov}=$ ovary; $\mathrm{Mg}=$ Mehlis' $\mathrm{g}$ land; $\mathrm{Pr}=$ prostatic reservoir; $\mathrm{Sv}=$ seminal vesicle; $\mathrm{Cs}=$ cirrus sac; $\mathrm{Ci}=$ cirrus; $U \mathrm{Ut}=$ uterus. Scale-bars: $A=500 \mathrm{~mm} ; B=100 \mathrm{~mm}, C, D$ and $E=50 \mathrm{~mm} ; F=100 \mathrm{~mm}$. 


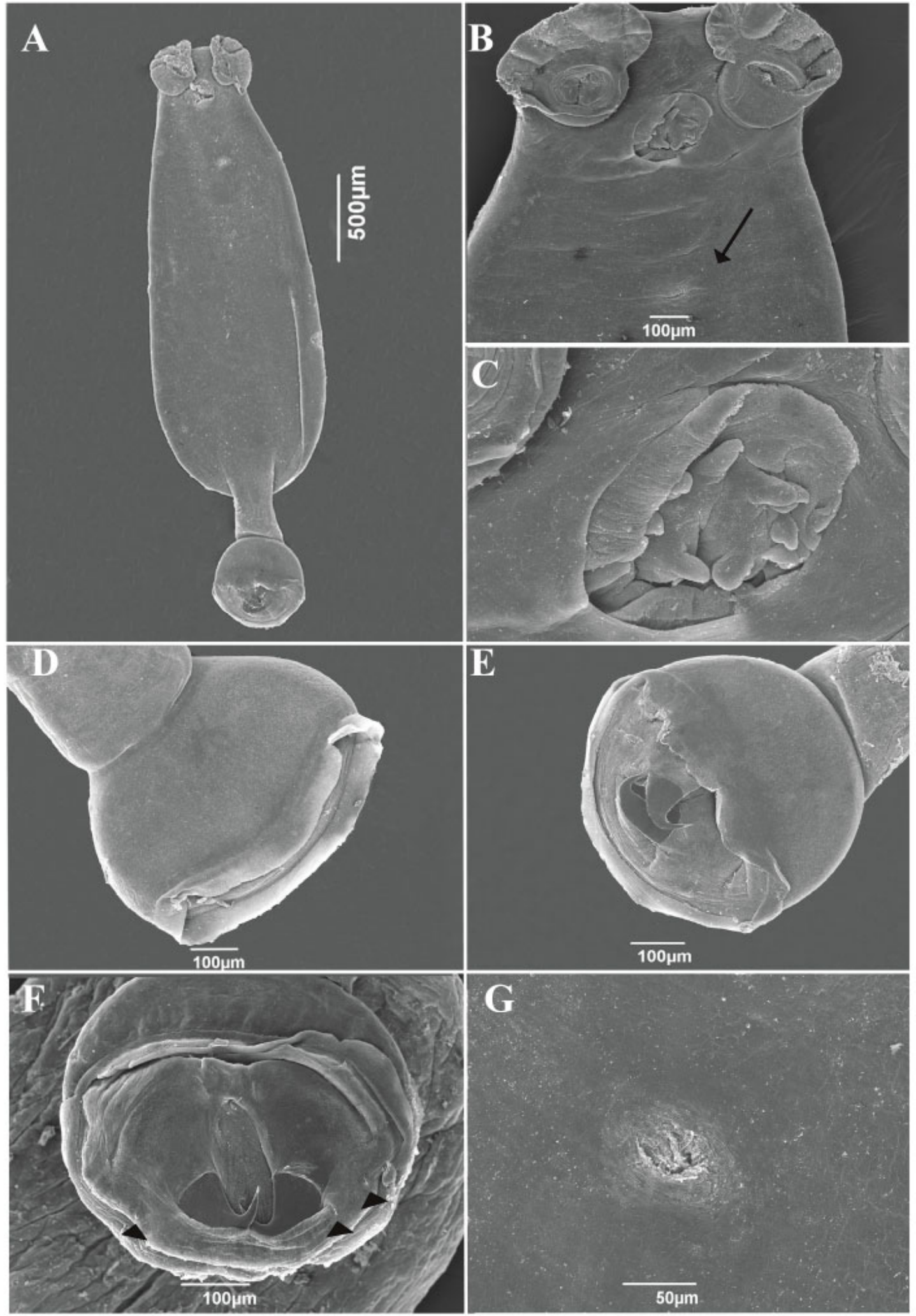

Fig 3. Scanning electron microscopy of Encotyllabe cf spari (A) Adult ventral view; (B) Anterior part of body with oral sucker; (C) Mouth bordered by digitiform projections; (D) Haptor with small membrane ; (E) Haptor with large anchors; (F) Details of large anchors; (G) Vaginal pore. 
marginal membrane (Fig. 3D - F). Large anchors with free tips (Fig. 3E - F) bordered by small hooks (arrowhead) (Fig. 3F). Vaginal pore, located mid-ventral and well posterior to the mouth (Fig. $3 B-G$, arrow).

\section{Genetic Analysis}

New sequences of $E$. cf. spari obtained in this study were deposited in the GenBank: these are the partial 18S rDNA (KY553150) (499bp) and partial 28S rDNA (KY553149) (796bp). For the partial $18 \mathrm{~S}$ rDNA, the BLAST result indicated that the present material had a $98 \%$ identity with Encotyllabe chironemi (AJ228780), with a $99 \%$ query cover and maximum score of 857 , followed by Megalocotyle marginata (KU872029), with a $91 \%$ identity, $93 \%$ query cover and maximum score of 632 , and Benedenia epinepheli (EU707802), with a $89 \%$ identity, $99 \%$ query cover and maximum score of 617 . For the partial 28S rDNA, the BLAST indicated Encotyllabe chironemi (AF382054) had a $99 \%$ identity, $100 \%$ query cover and a maximum score of 1,435 , followed by Encotyllabe and grouped with $100 \%$ statistical support. Encotyllabe cf. spari grouped in a clade with $E$. chironemi, with $99 \%$ support, closer than to Capsala martineri, with bootstrap support of $76 \%$ (Fig. 4). The tree topology of the phylogenetic analysis based on the partial 28S rDNA showed that the Dactylogyridae had a high level of support (99\%). A strongly supported (96\%) clade included Ligophorus uruguayensis and $L$. funellus (100\%) and two subclades, i.e. Mexicana rubra sp. nov., with a $93 \%$ bootstrap value, and Haliotrematoides spinatus $+H$. guttati $(99 \%)$. The basal clade comprised Bravohollisia rosetta and B. tecta, with $100 \%$ bootstrap.

The Capsalidae, with $100 \%$ statistical support, presented three clades: the Benedeniinae, Encotyllabinae and Capsalinae. The Benedeniinae was represented by Benedenia epinepheli and Benedenia lutjani with $99 \%$ of bootstrap grouped in a clade closer to Encotyllabinae represented by genera of Encotyllabe Diesing, 1850, with $78 \%$ support. Within the Encotyllabinae, three clades were formed; Encotyllabe caranxi appeared first, with $100 \%$ support, E. caballeroi grouped (87\% support) in a clade containing

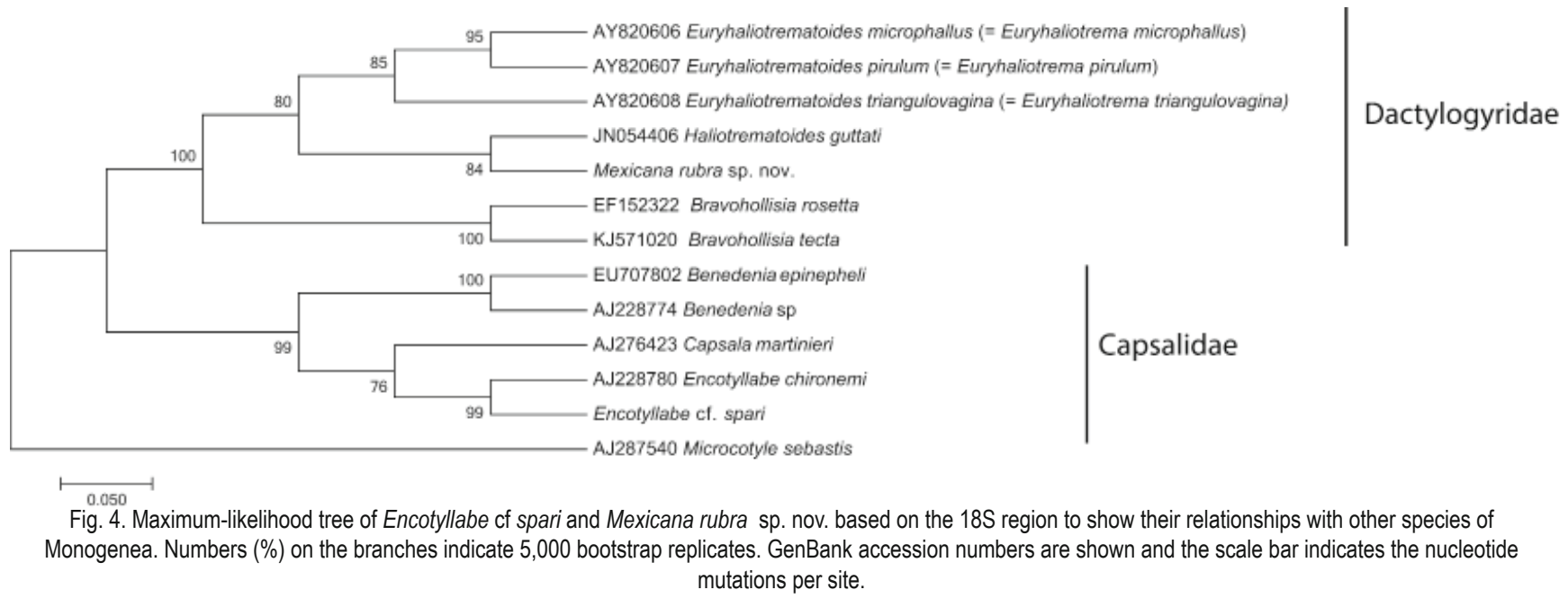

caballeroi (AF026112), with $98 \%$ identity, $99 \%$ query cover and maximum score of 1,393, and Encotyllabe caranxi (FJ971990) with $98 \%$ identify, $46 \%$ query cover and a maximum score of 647 .

\section{Phylogenetic analyses}

The tree topology of the phylogenetic analysis based on the $18 \mathrm{~S}$ rDNA of the two species studied here showed two main clades; one was included in the Dactylogyridae with $100 \%$ bootstrap support and the other in the Capsalidae with $99 \%$ support.

The clade formed by the Dactylogyridae showed that Euryhaliotrematoides microphallus grouped with $E$. pirulum, with a statistical support of $95 \%$, and E. triangulovagina, with a bootstrap value of $85 \%$. Mexicana rubra sp. nov. grouped with Haliotrematoides guttati, with an $84 \%$ bootstrap value and was closest to the Euryhaliotrematoides clade, with $80 \%$ support. Bravohollisia rosetta and $B$. tecta appeared in a basal clade, with a $100 \%$ bootstrap value. The Capsalidae, included Benedenia sp. and $B$. epinepheli,
E. cf. spari + E. chironemi (90\% support). Capsala martineri and Capsala laevis (Capsalinae) grouped with $100 \%$ of bootstrap in a basal clade (Fig. 5).

\section{Discussion}

Caballero and Bravo-Hollis (1959) proposed Mexicana in the Tetraonchidae Bychowsky, 1937, with the type species M. bychowskyi described from an unidentified host off the Pacific coast of Mexico. The generic diagnosis included six marginal hooks on the haptor and a postovarian testis. In 1961, these authors (Caballero and Bravo-Hollis, 1961) amended the generic diagnosis, referring eight marginal hooks and a bipartite testis; they also described M. littoralis from Haemulon sexfasciatum Gill, 1862 from the Gulf of California. According to Bychowsky (1957), members of the Tetraonchidae are characterized by having eight pairs of marginal hooks, two pairs of anchors, one bar and a single intestinal 


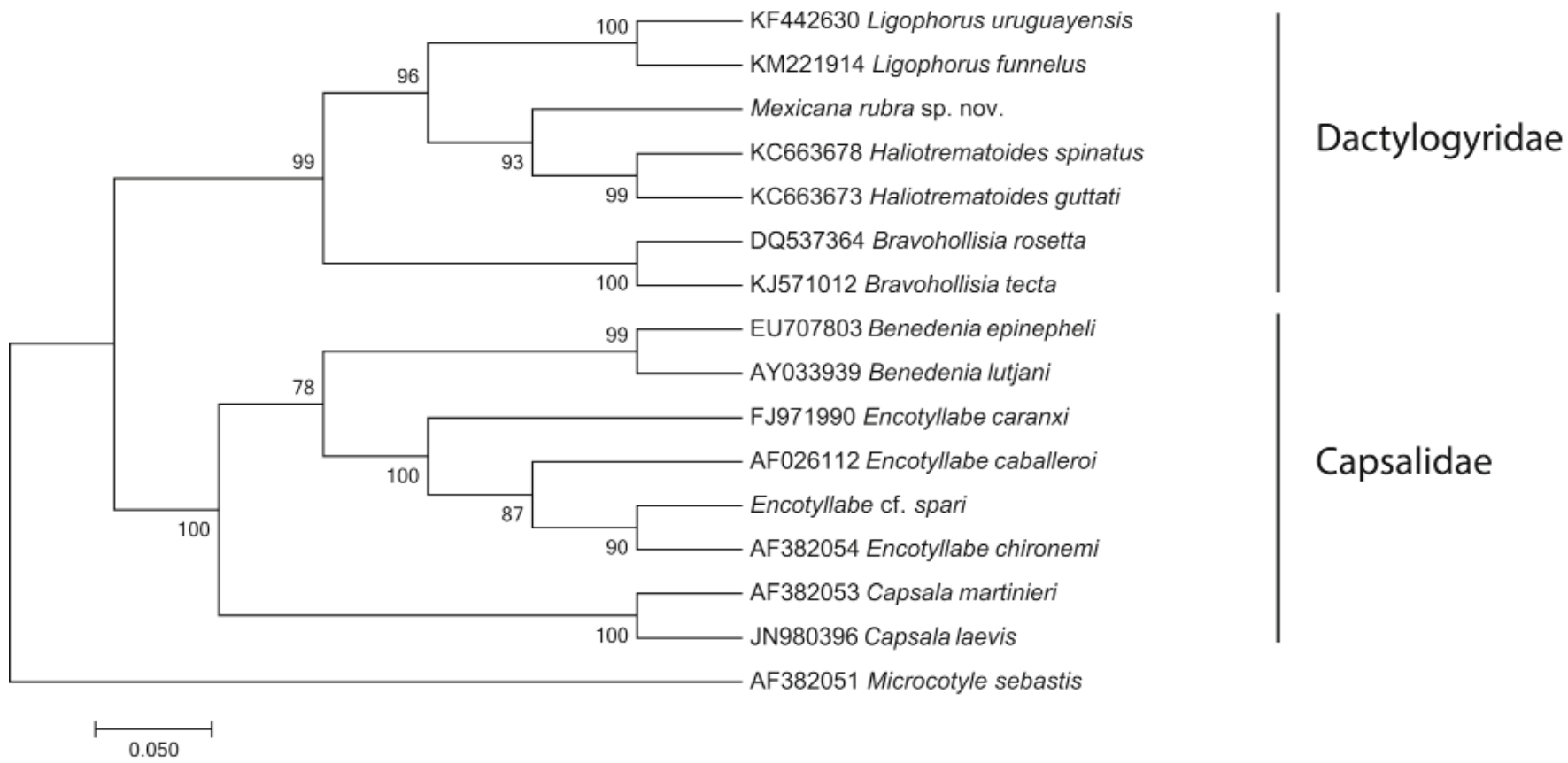

Fig. 5. Phylogenetic tree based on the maximum likelihood of the partial $28 S$ gene to show the relationship of Encotyllabe cf spari with other species of the Capsalidae. Numbers (\%) on the branches indicate 5,000 bootstrap replicates. GenBank accession numbers are shown and the scale bar indicates the nucleotide mutations per site.

cecum. Consequently, the genus was subsequently allocated to the Dactylogyridae (subfamily Ancyrocephalinae) by Luque et al. (1992), with an amended generic diagnosis and the description of M. atlantica from Haemulon steindachneri (Jordan \& Gilbert, 1882) off the cost of Brazil. The main generic characteristics are 14 similar hooks, two pairs of anchors, a dorsal bar with slender lateral ends, a ventral bar with wing-like expansions, intestinal ceca which are confluent posteriorly and a bipartite testis. In the original description of $M$. atlantica, the scale bar for figs 4 (dorsal bar) and 5 (ventral bar) were not in accordance with the measurements given. A re-examination of the paratypes (CHIOC nos. 33.109 and 33.110) showed that measurements given in the description are the correct ones.

Mexicana anisotremum, a species with an entire testis, was subsequently described from Anisotremus virginicus (Linnaeus, 1758) and $A$. surinamensis (Bloch, 1791) off Rio de Janeiro (Cezar et al., 2012). The most recent species to be described was $M$. iannaconi from $H$. steindachneri off Peru (Chero et al., 2014).

According to Chero et al. (2014), the main differential characters separating species of Mexicana are the morphology of testis, the sclerotized piece at the base of the copulatory organ and the ventral bar. They also proposed a key to the species, which they separated into two main groups, taking into account the morphology of testis: (1) testis bipartite posteriorly or completely bipartite ( $M$. atlantica, M. bychowskyi, M. littoralis and M. iannaconi) and (2) testis entire (M. anisotremum). Mexicana rubra sp. nov. is included in the first group. We could not find consistent differences in the piece at the base of the copulatory organ, but there are differences in relation to the shape of ventral and dorsal bars. The closest spe- cies to $M$. rubra sp. nov. is $M$. atlantica, and the main diagnostic features which differentiate the two are the ventral bar (with three deep bowed projections vs rectangular with shallow projections) and dorsal bar (with conspicuous deep indentations vs with lateral extremities enlarged, without indentations) (see the key to species proposed below). The shape of vagina in $M$. atlantica seems to be wider than in $M$. rubra sp. nov. Since it is not sclerotized, this may be a weak difference.

The present sequences for the 18S, ITS1 and 5.8S and 28S of Mexicana rubra sp. nov. represent the first available genetic data for the genus. The $18 \mathrm{~S}$ and $28 \mathrm{~S}$ rRNA genes are known to be conserved, with lower sequence variation, compared with the ITS1 (Schlötterer et al., 1994). The ML trees using partial $18 S$ and $28 S$ sequences shows that the new species nest as the sister taxa of other dactylogyrid genera, i.e. Euryhaliotrema, Haliotrematoides, Ligophorus and Bravohollisia, because correlation has a statistical significance. Sequences of ITS1 and 5.8S were not used in the phylogenetic reconstruction due to their low query cover.

The Capsalidae was previously referred as monophyletic by Mollaret et al. (1997), Whittington (2004) and Perkins et al. (2009). Whittington (2004) considered that some capsalid subfamilies and genera are ill-defined and require taxonomic revision. Members of Encotyllabe parasitize a wide range of teleost fishes from different geographical areas. Yamaguti (1934) described E. spari from the gills of Sparus macrocephalus (Basilewsky, 1855), Plectorynchus pictus (Thunberg, 1792) and Epinephalus akaara (Temminck \& Schlegel, 1842) from the Inland Sea of Japan. Kohn et al., (1984) reported this species from Haemulon sciurus (Shaw, 1803) and Luque et al. (1996) from O. ruber off the coast of Rio de Janeiro. 
This species was also reported from the gills of Plectorhynchus cinctus (Temminck \& Schlegel, 1843), P. pictus (Thunberg, 1792) and $P$. schotaf (Forsskål, 1775) from the Arabian Gulf (Khalil et al., 1988) and from Carangoides bajad (Forsskål, 1775) in Kuwait Bay (Kardousha et al., 2002). Our specimens exhibit small differences compared with Yamaguti's original description and, consequently, we have referred to them as $E$. cf. spari.

According to Sepúlveda et al. (2014), the taxonomic status of members of Encotyllabe is questionable, the problem being the deficient or incomplete descriptions and/or illustrations of many of the nominal species. The best characteristics for identifying specimens would appear to include body shape, with thin lateral margins which are turned ventrally, the shape and relative position of the testes, the shape of the cirrus, the extent of the vitelline field, caeca which are not confluent, and the size and shape of the anchors (Yamaguti, 1963; Khalil \& Abdul-Salam, 1988; Williams \& Beverley-Burton, 1989).

Khalil and Abdul-Salam (1988) showed a general ultrastructural view of the body of $E$. spari and we add new information on the mouth with several digitiform projections, detail of the haptor bordered by a narrow membrane, and the shape of the anchors and hooks. Additionally, our sequences of the partial $18 \mathrm{~S}$ and $28 \mathrm{~S}$ of E. cf. spari show the position of the species within the Capsalidae, together with species of Benedenia and Capsala with a high statistical support (99\%). In the GenBank, the analysis of the partial 18S rDNA gene included a single sequence of Encotyllabe (E. chironemi - AJ228780) for comparison with E. cf. spari (query cover $99 \%$, identity $98 \%$ ). The presence of only two sequences of $E n-$ cotyllabe influenced the tree topology, grouping Encotyllabe with Capsala martinieri Bosc, 1811 (AJ276423) with a statistical support of $76 \%$. The analysis of the partial 28S rDNA, with a greater number of representative species of Encotyllabe, showed Encotyllabe spp. to be closer to the Benedenia clade with low statistical support (78 \%) and well separated from Capsala clade with $100 \%$ support. Therefore, more new sequences of Encotyllabe species are required to augment the genetic profile of the genus.

This work provided the description of a sixth species of Mexicana, including new genetic data based on the ITS1, 5.8S and partial 18S and $28 \mathrm{~S}$ rDNA, and new data on the genetic profile of $E$. cf. spari based on the partial 18S and 28S rDNA genes plus new ultrastructural data. A key to the species of Mexicana is proposed below.

Key to the species of Mexicana.

1. Parasites of fishes in the Pacific Ocean....................................... Parasites of fishes in the Atlantic Ocean................................. 4

2. Testis completely bipartite......................................... iannaconi Testis bipartite only posteriorly..................................................

3. Body length 576 - 736; pharynx length $55-66$; ventral anchor 40 -42 long; dorsal anchor $30-42 \mu \mathrm{m}$ long..................... bychowskyi Body length 951 - 1057; pharynx length 70 - 74; ventral anchor 20 25 long; dorsal anchor $20-21 \mu \mathrm{m}$ long............................ littoralis

4. Testis entire; male copulatory organ tubular, without expanded piece at base...... M. anisotremum
Testis bipartite posteriorly; male copulatory organ tubular, with expanded piece at base .........................................................

5. Ventral bar rectangular with shallow projections; dorsal bar elongate, with lateral extremities enlarged, lacking deep antero-lateral indentations...................................................................... atlantica Ventral bar with three deep bowed projections; dorsal bar elongate with conspicuous deep antero-lateral indentations.

.... rubra sp. nov.

\section{Acknowledgements}

The authors are grateful to Dr Gerardo Ponce de Leon and Luis Garcia from UNAM for providing micrographs of CNHE material, to Dr David I. Gibson from Natural History Museum, London for comments and to Ana Cristina Ferreira for technical support. This study was authorized by the Brazilian Institute of Environment and Renewable Natural Resources (IBAMA, license no. 15898-1). The study was financially supported by Conselho Nacional de Desenvolvimento Científico e Tecnológico (CNPq- Universal no. 449658/2014-7), Coordenação de Aperfeiçoamento de Pessoal de Ensino Superior (CAPES-Parasitologia 247/2012), Fundação Oswaldo Cruz (PAEF no. IOC-008-FIO-04) and Universidade Federal Rural do Rio de Janeiro. This study is part of the PhD's thesis of the first author as part of the Programa de Pós-Graduação em Ciências Veterinárias, Universidade Federal Rural do Rio de Janeiro.

\section{References}

Altschul, S.F., Gish, W., Miller, W., Myers, E.W., Lipman, D.J. (1990): Basic local alignment search tool. J. Mol. Biol., 215(3): 403 - 410. DOI: 10.1016/s0022-2836(05)80360-2

Aмато, J.F.R. (1982a): Digenetic trematodes of percoid fishes of Florianopolis southern Brasil - Bucephalidae. Rev. Bras. Biol., 42(4): $667-680$

Амато, J.F.R. (1982b): Digenetic trematodes of percoid fishes of Florianopolis southern Brasil - Fellodistomidae, Monascidae, Diplangidae, Zoogonidae, and Waretrematidae, with description of two new species. Rev. Bras. Biol., 42(4): 681 - 699

AмAто, J.F.R. (1982c): Digenetic trematodes of percoid fishes of Florianopolis southern Brasil - Monorchiidae, with description of two new species. Rev. Bras. Biol., 42(4): 701 - 719

AmAтo, J.F.R. (1983a): Digenetic trematodes of percoid fishes of Florianopolis southern Brasil - Homalometridae, Lepocreadiidae and Opecoelidae, with the description of seven new species. Rev. Bras. Biol., 43(1): 73 - 98

AmATo, J.F.R. (1983b): Digenetic trematodes of percoid fishes of Florianopolis southern Brasil - Pleorchiidae, Didymozoidae and Hemiuridae, with the description of three new species. Rev. Bras. Biol., 43(1): 99 - 124

BASHIRULLAH, A.K.M., RadO, N.E., (1987): Co-occurrence of three species of Choricotyle (Monogenea: Diclidophoridae) in the grunt Orthopristis ruber and their host-specificity. J. Fish. Biol., 30(4): 419 - 422. DOI: 10.1111/j.10958649.1987.tb05765.x 
Bychowsky, B.E. (1957): [Monogenetic trematodes, their systematics and phylogeny]. Moscow, Russian, Academiya Nauk, 509 pp. (In Russian) (translated to English in 1961, American Institute of Biological Sciences, Washington, D.C., 627 pp.)

Billings, A.N., Teltow, G.J., Weaver, S.C., Walker, D.H. (1998): Molecular characterization of a novel Rickettsia species from IXodes scapularis in Texas. Emerg. Infect. Dis., 4(2): 305 - 309. DOI: 10.3201/eid0402.980221

BuRKEnROAd, M. (1930): Sound production in the Haemulidae. Copeia, 1930(1): 17 - 18. DOI: 10.2307/1436165

Bush, A.O., LAfFerty, K.D., Lotz, J.M., Shostak, A.W. (1997): Parasitology meets ecology on its own terms: Margolis et al. Revisited. J. Parasitol., 83(4): 575 - 583. DOI: 10.2307/3284227

Caballero, E., Bravo-Hollis, M. (1959): Tremátodos de peces de aguas Mexicanas del Pacífico. XVII. Dos nuevos géneros de Monogenoidea Bychowsky, 1937 [Trematodes of fish from Pacific Mexican waters. XX. Two new genera of Monogenoidea Bychowsky, 1937]. Anales Inst. Biol. Univ. Nac. Autón. México (Serie Zoologia), 30: 167 - 181

Caballero, E., Bravo-Holuls, M. (1961): Tremátodos de peces de aguas Mexicanas del Pacífico [Trematodes of fish from Pacific Mexican waters]. XX. Anales Inst. Biol. Univ. Nac. Autón. México (Serie Zoologia), 32: $201-217$

Cezar, A.D., Paschoal, F., Luque, J.L. (2012): A new species of Mexicana (Monogenea: Dactylogyridae) parasitic on two species of Anisotremus (Perciformes: Haemulidae) from the Brazilian coastal zone. Neotrop. Helminthol., 6(1): 25 - 29. Retrieved July 20, 2015 from http://sisbib.unmsm.edu.pe/bvrevistas/neohel/v6n1/ pdf/a03v06n1.pdf

Chero, J., Cruces, C., Sáez, G., Alvariño, L. (2014): Mexicana iannaconi. n. sp. (Monogenea: Ancyrocephalidae) parasite of ChereChere Grunt Haemulon steindachneri (Jordan \& Gilbert, 1882) (Perciformes: Haemulidae) from the Peruvian Coast. Neotrop. Helminthol., 8(2): 429 - 438. Retrieved August 10, 2015 from http:// sisbib.unmsm.edu.pe/BVRevistas/neohel/v8n2/pdf/a21v8n2.pdf Chisholm, L.A., Morgan, J.A.T., Adlard, R.D., Whittington, I.D. (2001): Phylogenetic analysis of the Monocotylidae (Monogenea) inferred from 28S rDNA sequences. Int. J. Parasitol., 31: 1253 1263. DOI: 10.1016/s0020-7519(01)00223-5

FELSENSTEIN, J. (1981): Evolutionary trees from DNA sequences: a maximum likelihood approach. J. Mol. Evol., 17: 368 - 376. DOI: $10.2307 / 2408134$

Kardousha, M.M. (2002): Descriptions of three Capsala spp. (Capsalidae) including Capsalla naffai n.sp. infectinf mackerel tuna Euthynnus affinis from coast of Emirates. Parasitol. Int., 51(4): 327 - 335. DOI: 10.1016/s1383-5769(02)00033-8

KhalIL, L.F., Abdul-SalAm, J.B. (1988): The subfamily Encotyllabinae (Monogenea: Capsalidae) with the description of Alloencotyllabe caranxi n. g., n. sp. and Encotyllabe kuwaitensis n. sp. Syst. Parasitol., 11: 139 - 150. DOI: 10.1007/bf00012264

Kohn, A., Abramson, B., Macedo, B. (1984): Studies on some monogenean parasites of Haemulon sciurus (Shaw, 1803) (Po- madasyidae). J. Helminthol., 58: 213 - 218. DOI: 10.1017/ s0022149x00026997

Kumar, S., Stecher, G., Tamura, K. (2015): MEGA7: Molecular Evolutionary Genetics Analysis version 7.0. MolecularBiology and Evolution (submitted). (Publication PDF at http://www.kumarlab. net/publications)

Luque, J.L., Amato, J.F.R. Takemoto, R. (1992): A new species of Mexicana Caballero y Bravo-Hollis (Monogenea: Dactylogyridae) parasitic on Haemulon steindachneri (Jordan y Gilbert) (Osteichthyes: Haemulidae) from the Brazilian coast. Rev. Bras. Parasito. Vet., 1: 85 - 88. Retrieved April 15, 2015 from http://cbpv.org.br/ rbpv/documentos/121992/c1285_88.pdf

LUque, J.L., Amato, J.F.R., TAKemoto, R. (1993a): Four species of Choricotyle van Beneden (Monogenea: Diclidophoridae) parasitic on Orthopristis ruber (Cuvier) (Osteichthyes: Haemulidae) from the Brazilian coast, with description of two new species. Rev. Bras. Parasitol. Vet., 2(1): 15 - 24. Retrieved March 15, 2015 from http:// cbpv.org.br/rbpv/documentos/211993/c2115_24.pdf

LUQUe, J.L., AmATo, J.F.R., TAKEMoto, R. (1993b): A new species of Pseudotagia Yamaguti (Monogenea: Macrovalvitrematidae) parasitic on Orthopristis ruber (Cuvier) (Osteichthyes: Haemulidae) from the Brazilian coast. Rev. Bras. Parasitol Vet., 2(2): 111 - 114. Retrieved March 15, 2015 from http://cbpv.org.br/rbpv/documentos/221993/c22111_114.pdf

Luque, J.L., Amato, J.F.R., Takemoto, R.M. (1996a): Comparative analysis of communities of metazoan parasites of Orthopristis ruber and Haemulon steindachneri (Osteichthyes: Haemulidae) from the southeastern Brazilian littoral: I - structure and influence of the size and sex of host. Rev. Bras. Biol., 56(2): $279-292$

Luque, J.L., Amato, J.F.R., TAKemoto, R.M. (1996b): Comparative analysis of communities of metazoan parasites of Orthopristis ruber and Haemulon steindachner (Osteichthyes: Haemulidae) from the southeastern Brazilian littoral: II - Diversity, interspecific associations, and distribution of gastrointestinal parasites. Rev. Bras. Biol., 56(2): 293 - 302

Menezes, N.A., Figueiredo, J.L. (1980): Manual de peixes marinhos do sudeste do Brasil. IV. Teleostei (3) [Manual of marine fishes of Southeast Brazil. IV. Teleostei (3)]. São Paulo, Museu de Zoologia, Universidade São Paulo, 96 pp.

Mollaret, I., Jamieson, B.G.M., Adlard, R.D., Hugall, A., Lecointre, G., Chombard, C,. Justine, J.L. (1997): Phylogenetic analysis of the Monogenea and their relationships with Digenea and Eucestoda inferred from 28S rDNA sequences. Mol. Biochem. Parasitol., 90: 433 - 438. DOI: 10.1016/s0166-6851(97)00176-x

Palazón-Fernández, J.L. (2007): Reproduction of the white grunt, Haemulon plumieri (Lacépede, 1802) (Pisces: Haemulidae) from Margarita Island, Venezuela. Sci. Mar., 71(3): 429 - 440. DOI: 10.3989/scimar.2007.71n3429

Paschoal, F., Cezar, A.D., Luque, J.L. (2015): Checklist of metazoan associated with grunts (Perciformes, Haemulidae) from the Nearctic and Neotropical regions. Check List, 11: 1 - 23. DOI: 10.15560/11.1.1501 
Paschoal, F., Vieira, F.M., Cezar, A.D., Luque, J.L. (2014): Dichelyne (Cucullanellus) tornquisti $\mathrm{n}$. sp. (Nematoda: Cucullanidae) from corocoro grunt, Orthopristis ruber (Cuvier, 1830) (Perciformes: Haemulidae) from southeastern Brazil. J. Parasitol., 100: 215 - 220. DOI: 10.1645/13-334.1

Perkins, E.M., Donnellan, S.C., Bertozzi, T., Chisholm, L.A., WhitTINGTON, I.D. (2009): Looks can deceive: Molecular phylogeny of a family of flatworm ectoparasites (Monogenea: Capsalidae) does not reflect current morphological classification. Mol. Phylogenet. Evol., 52(3): 705 - 714. DOI: 10.1016/j.ympev.2009.05.008

Schlötterer, C., Hauser, M.T., von Haeseler, A., Tautz, D. (1994): Comparative evolutionary analysis of rDNA ITS regions in Drosophila. Mol. Biol. Evol., 11(3): 513 - 522. DOI: 10.1093/oxfordjournals.molbev.a040131

Sepúlveda, F.A. González, M.T., Oliva, M.E. (2014): Two new species of Encotyllabe (Monogenea: Capsalidae) based on morphometric and molecular evidence: parasites of two inshore fish species of northern Chile. J. Parasitol., 100(3): 344 - 349. DOI: 10.1645/13-230.1

Sinnappah, N.D., Lim, L.H.S., Rohde, K., Tinsley, R., Combes, C., VeRnEAU, O. (2001): A pleomorphic parasite associated with a neotenic amphibian host: phylogenetic evidence suggests a revised systematic position for Sphyranuridae within anuran and turtle polystomatoineans. Mol. Phylogenet. Evol., 18(2): 189 - 201. DOI: 10.1006/mpev.2000.0877
TAVOLGA, W.N., Wodinsky, J. (1965): Auditory capacities in fishes: threshold variability in the blue-striped grunt Haemulon sciurus. Anim. Behav., $13(2-3)$ : 301 - 311. DOI: 10.1016/00033472(65)90050-3

THOMPson, J.D., HIGGINS, D.G., GIBSON, T.J. (1994): CLUSTAL W: improving the sensitivity of progressive multiple sequence alignment through sequence weighting, position-specific gap penalties and weight matrix choice. Nucleic. Acids. Res., 22(22): 4673 4680. DOI: 10.1093/nar/22.22.4673

VIGNON, M., SASAL, P. (2010): The use of geometric morphometrics in understanding shape variability of sclerotized haptoral structure of monogeneans (Plathelmintes) with insights into biogeographic variability. Parasitol. Int., 59(2):183 - 191. DOI: 10.1016/j. parint.2010.01.006

Whittington, I.D. (2004): The Capsalidae (Monogenea: Monopisthocotylea): a review of diversity, classification and phylogeny with a note about species complexes. Folia Parasitol., 51(2): 109 - 122. DOI: 10.14411/fp.2004.016

Williams, A., Beverley-Burton, M. (1989): Redescription of three species of the genus Encotyllabe (Capsalidae: Monogenea) from fishes of the east coast of Australia. Aust. J. Zool., 37(1): 45 - 53. DOI: 10.1071/zo9890045

YAGAMUtI, S. (1934): Studies on the helminth fauna of Japan. Pt. 2. Trematodes of fishes. I. Jpn. J. Zool., 5: 265 - 266

YAmAGUtI, S. (1963): Systema Helminthum. Vol. IV. Monogenea \& Aspidocotylea. New York, Interscience Publication, pp. 699. 